\title{
HIGHER EDUCATION AND ECONOMIC GROWTH A CASE STUDY OF PAKISTAN
}

\author{
By \\ Muhammad Tariq Mahmood $^{\bullet}$ \\ Sadaf Shahab
}

\section{Abstract}

This paper highlights the role of higher education for the economic growth in Pakistan. We explore the impact of increase in enrolment at tertiary level on the growth rate of income per worker. Estimating a growth model developed by Mankiv et. al. (1992), using the annual data of Pakistan, we find a robust relationship between higher education and economic growth in the long run. The model has also shown that investment in fixed capital has positive impact on economic uplift. Applying Johansen's cointegration test, we show that the long run elasticity of income with respect to capital stock is different from its share in GDP, and increase in the enrolment per unit of effective worker helps in bolstering economic growth. But, like earlier literature we also find statistically insignificant relationship between higher education and GDP per worker. There are some fundamental reasons concerning to the ambiguous impact of investing in human capital on economic growth, particularly in the short run in case of Pakistan. First, the sharp increase in enrollment, recently, has been damaging the quality of education. Second, the unequal distribution of educational services has held back the efficiency of public expenditures, particularly before the reforms undertaken by higher education commission. Third, the low private return of education has limited the demand for higher education in Pakistan for almost fifty years.

\section{Introduction}

Higher education strongly affects the economy, society, and culture of a country. The colleges and universities are viewed as powerful engines of economic growth and cultural transition. Particularly higher education is often seen as vital for the continued growth. In the context of developing world generally and for Pakistan particularly, last two decades have been turbulent period for higher education, marked by profound demographic shifts, a higher increase in returns in services sector and significant changes in the nations' economy.

This paper highlights the role of higher education in the economic growth in case of Pakistan. We explore the impact of increase in enrollment at tertiary level on the growth rate of income per worker. The growth model developed by Mankiv et. al. (1992) has been tested using the annual data. Examining the link between higher education and economic growth through employment factor is for two reasons: first, participation in higher education is non-compulsory

\footnotetext{
- The writer is working as a Lecturer, Department of Economics, Allama Iqbal Open University and Ph.D. Schaolar at Federal Urdu University of AS and T, Islamabad tm76pk@gmail.com

• The writer is working as a Lecturer and Ph.D. Scholar at Department of Economics, Federal Urdu University of AS and T, Islamabad
} 
and depends on individual educational choice; second, there is strong empirical evidence for the hypothesis that physical and human capitals are strongly complementary production factors (Goldin and Katz (1998); Krusell, et.al. (2000).

The World Bank had published Knowledge for Development, a report in 1999 that looked at how developing countries could use knowledge to narrow the income gap with rich world economies. It showed a correlation between education in mathematics, science, and engineering and improved economic performance. It also showed that the private rate of return to tertiary education was similar to that for secondary schooling. The report recommended that developing countries should train teachers using distance learning and other techniques to fasten the pace of economic growth via human capital, particularly at tertiary level.

\section{Objectives of the Study}

1. To explore the role of increase in higher education attainment as determinant of economic growth.

2. To check whether the focus of government policy should rest on the enhancement of higher education.

3. Further, this study will also be a roadmap for researchers to probe the subject of higher education and economic growth in case of developing countries.

\section{Higher Education System in Pakistan}

Education above grade 12 is considered as higher education in Pakistan, wherein the age group of 17 to 23 years falls. The tertiary system in Pakistan comprises two main categories: firstly, the Degree Awarding Institutes (DAI) or universities where direct education is provided and secondly a stream of affiliated Colleges, which do not possess degree awarding status directly. The governing body of the tertiary education system is Higher Education Commission (HEC) which is responsible for allocating public funds from the federal government to universities and DAIs and accrediting their degree programmes along with bolstering of research and development activities in the education institutions. Colleges are funded and regulated by provincial governments, but follow the curriculum of the universities with which they are affiliated. The HEC primarily funds public universities, but recently it has opened a limited number of possibilities for making funds available to private sector universities for research and infrastructure development purposes.

The higher education sector enrolls about $0.6 \%$ of the total population and almost $2 \%$ of total employed labor force in Pakistan. Figure 1 presents the international comparison of selected countries, both developing and developed. The gap between developing nations and developed ones is quite visible. In the south Asian region Pakistan's performance is less than Indian, Bangladesh, and Nepal.

\section{Figure - 1}

\section{Tertiary Enrollment as percent of Total Population and Employment ${ }^{1}$}

\footnotetext{
${ }^{1}$ Authors' Calculations, data source: UIS, UNESCO
} 


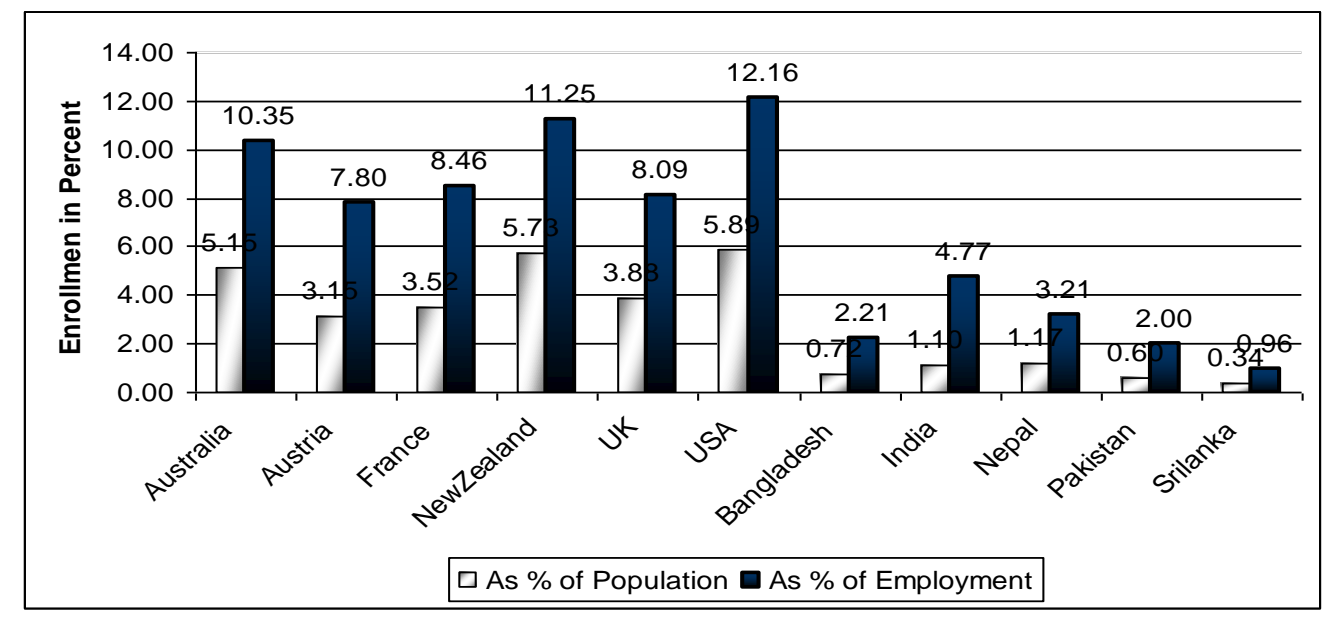

The prime objective of the universities is the research and development. In Pakistan the bulk of research is conducted in public universities. However, the private sector does play an important role. Private universities have also launched many research activities and journal and encourage their faculty and students in the conduct of meaningful inquiries to strengthen the capacity of utilization of higher education.

Government Policy Reforms: After serious neglect of many years, the higher education in Pakistan has recently undergone a renaissance. As it is evident in Table 1 below, that government increased spending on higher education with the beginning of twenty first century, which shows a clear commitment to improving higher education structure in the county. Despite its achievements in recent years, higher education sector in Pakistan still faces some challenges like; quality, management, access to the remote population, success of faculty development programs, link between HEC and universities, governance of higher education institutions and relevance of higher education to the labor market. But, HEC and concerned institutions are not ignorant to these challenges e.g., measures have been taken to solve the access issues by expanding existing physical infrastructure, exploration of the distance learning opportunities and provision of scholarships to students in both the public and private sectors.

Table - 1

Development and Non-development expenditure on Higher Education ${ }^{2}$

\begin{tabular}{|l|c|c|c|c|c|c|c|}
\hline \multicolumn{10}{|c|}{ Rs. Million } \\
\hline Years & $\mathbf{2 0 0 2 - 0 3}$ & $\mathbf{2 0 0 3 - 0 4}$ & $\mathbf{2 0 0 4 - 0 5}$ & $\mathbf{2 0 0 5 - 0 6}$ & $\mathbf{2 0 0 6 - 0 7}$ & $\mathbf{2 0 0 7 - 0 8}$ & $\mathbf{2 0 0 8 - 0 9}$ \\
\hline $\begin{array}{l}\text { Released } \\
\text { Recurring }\end{array}$ & 3443.39 & 5304.647 & 6995.608 & 10493.41 & 14332.52 & 12536.5 & 10248.18 \\
\hline $\begin{array}{l}\text { Released } \\
\text { Development }\end{array}$ & 4280.009 & 4968.45 & 8940.076 & 10890.88 & 14409.16 & 15390.46 & 8167.76 \\
\hline $\begin{array}{l}\text { Released } \\
\text { Total }\end{array}$ & 7723.399 & 10273.1 & 15935.68 & 21384.29 & 28741.68 & 27926.95 & 18415.94 \\
\hline
\end{tabular}

\section{Review of Literature}

\footnotetext{
${ }^{2}$ Source: Economic Survey of Pakistan 2008-09. This table also shows a cut-down in public spending on higher education in last two fiscal years, particularly during 2008-09.
} 
Despite its significance for economic growth, education sector has been a neglected portion in literature on economic development in developing countries; particularly the issue of higher education has been a heated discussion in academia in economics. Most of the work done so far, shows that higher education does not affect economic growth, significantly. [Islam (1995); Caselli et.al. (1996) and Pritchett (1996)]

Education, including both technical training and general education, contributes to economic growth through its ability to increase the productivity of the population or the labor force in particular, which leads to increase in individuals' earnings. The question of importance of human capital towards economic growth does not find robust answer in cross country evidence done by Caselli and Lefort (1996) and Mankiv, et al. (1992). Both studies, using panel data conclude that the direct investment in human capital has not put any significant impact on economic growth. Pritchet (1996) wonders about the utility of schooling expenditures and found no positive relationship between educational attainment and GDP per worker.

A credible explanation of the issue of insignificant impact of education on economic growth may come from the fact that the quality of educational systems varies across the countries [see Hanushek and Kim (1995) and Barro and Lee (1996)]. The significance of labour force quality is an important factor of international differences in per capita growth rates and inferred that labor force quality was connected with educational infrastructures.

The growth accounting approach and the rate of return to human capital approaches were used to investigate the contribution of higher education on economic growth. Several studies have investigated the relationship between economic growth and education such as Psaharoupolous, 2002; Mankiv et. al.(1992); Pencavel, 1993 and De Meulmester and Rochet, 1995. A handsome number of studies focus on cross country analysis [Mankiv et. al. (1992); Pencavel (1993); Psacharopoulos (1994); Hanushek and Kim (1995); Caselli and Lefort (1996); Lee and Baro (1996); Bloom et. al. (2005); Osipian (2007;]. Whereas researchers, such as Pencavel (1993), affirmed that correlations exist across countries between economic growth rates and enrollment in higher education.

On the role of different levels of education, Azariadis and Drazen (1990) and Cohen (1996) show marginal deviations on the roles of relative levels of education from what the earlier research indicated and found that it is the secondary level of education that has a more significant effect on income distribution, and that primary education may not be adequate to produce any recognizable effect on the distribution and level of income. The question of the significant associations between higher education and the labor market are also among the key issues of debate whenever innovations in higher education are considered (Teichler, 1999). The World Bank, in its report titled Higher Education: Lessons of Experience, mentioned the relation between higher education and employment as one of the key elements of the higher education crisis related to mismatch of supply and demand of graduates and lack of contact with the market. ${ }^{3}$

\footnotetext{
${ }^{3}$ In addition to this report by WB, World Conference on Higher Education organized by UNESCO stated that the demands of labor market are changing dramatically. The pattern of employment is also changing making the college courses obsolete for the demands of labor market
} 
Three factors are very significant to this situation: the higher education institutions, the private economic sector and governments. These players interconnect and affect important variables that are the focus of this study: higher education, economic growth and employment.

Employment is an influential factor and the students are found to be very responsive to tuition, scholarship and part-time employment opportunities in deciding which institution to attend (Maski and Wise, 1983). Future salaries are also highly related particularly by private business and industries shape the decision of students in opting educational fields like business administration, medical, engineering, economics and, most recently, the computer sciences. Willis and Rosen (1979) found that this sensitivity to the issue of monetary concerns is important and estimated that a percentage increase in starting salaries result into almost a double increase in higher education enrolments.

\section{Methodological Framework}

An annual data set from 1982 to 2007 was considered for trivariate relationships between higher education and economic growth in the presence of the employment variable. To test this relationship we need to investigate the time series properties; first, to test whether the series are stationary at level or fist difference, second, whether they are co-integrated or not. Many theorist of this type of study have used causality analysis, while some estimated the production function through different econometric techniques; particularly Ordinary Least Squares and Generalized Least Squares. Since a handsome number of researchers used the panel data, the use of Panel GLS, GMM and Fixed effect and random effect models for analysis is found repeatedly in the literature. Our approach to tackle the issue is different from previous ones. We are using Mankiv et.al.(1992) model on human capital to test the long run relationship between the human capital ${ }^{4}$ and economic development in case of Pakistan, using Johanson's cointegration methodology. This methodology is based on error correction representation of a VAR of order (p).

If the series are non-stationary but follow a unique order of integration, i.e., I(1) then ordinary least squares can be applied after transforming the series into first difference form. But for long run analysis we need to use Johanson's test.

\section{The Model}

The Mankiv et. al. (1992) approach to develop links between income per worker and level of higher education per effective labor. The analysis which Mankiv et al. presented follows the footprints of textbook Solow growth model. The model assumes exogenous rate of growth of labor and technology $n$ and $g$ respectively, with a constant depreciation rate $\psi$

$$
Y_{t}=A_{t} K_{t}^{a} L_{t}^{1-a}
$$

Here $Y$ is output, $K$ capital, $L$ Labor and $A$ the level of technology. The steady state solution of equation (1) takes the following reduced form;

$$
y_{t}=\beta_{0}+\beta_{1} k+\beta_{2} \ln (n+g+\psi)_{t}+u_{t}
$$

In equation (2) $y_{t}=Y / A L, k=K / A L$, are quantities per effective unit of worker. $u_{t}$ is white noise error. In simple form of the Solow model the variable of human capital has been a component of error term. Next we add human capital to the textbook Solow's model

\footnotetext{
${ }^{4}$ To be in line with the prime objective of this study, we have used enrollment in higher education as proxy for human capital with some standard assumptions.
} 


$$
Y_{t}=A_{t} K_{t}^{a} H_{t}^{b} L_{t}^{1-a-b}
$$

Where $H$ is stock of human capital and all other variables are defined as before. The steady state solution of equation (3) results into following reduced form representation:

$$
y_{t}=\lambda_{0}+\lambda_{1} k_{t}+\lambda_{2} \ln (n+g+\psi)_{t}+\lambda_{3} h_{t}+\eta_{t}
$$

Where $h_{t}$ is human capital per effective unit of worker and $\eta_{t}$ is white noise error. All other variables are defined as before. All the variables used in reduced form equations are in log. In equation (4) we can predict two possible ways of estimation: one way in which we can use rate of human capital accumulation and second, where we can use level of human capital. In the model we present the level of human capital instead of rate of accumulation of human capital. For this study we use equation (4) for empirical analysis, where we also predict that $\alpha+\beta<1$.

\section{Data}

Data used in this study was obtained from several sources. Economic figures are obtained mainly from the Economics Survey of Pakistan, employment figures are obtained from World Development Indicators and higher education figures were obtained mainly from the UNESCO Institute of Statistics (UIS) and Economic Survey of Pakistan. Annual data for the examined variables was obtained for the period 1982-2007. The variables involved are the number of students per employed person enrolled in higher education institutions of Pakistan (taken as a proxy for the higher education), the Gross Domestic Product per employed person (constant prices) and physical capital per employed person.

\section{Results}

Our empirical results for the long run connection between human capital in shape of tertiary education and economic development rests on three steps: firstly we presented the results of unit root test to check the stationarity of the data; secondly the ordinary least squares (OLS) estimators of transformed model are given; and thirdly we use VAR model to test for cointegration and compare normalized co-efficient with those of differenced equation results obtained through OLS.

\section{Test for Stationarity}

First, variables were tested for stationarity. All the variables are non-stationary at level; thus, are transformed taking first differences of logarithms because unit root in the series prohibit use of OLS at level. This also provides the rationale of applying cointegration test. The results of Augmented Dickey and Fuller test are reported in Table 2.

Table -2

Unit Root Tests- Log Transformed Series (1986-2007)

\begin{tabular}{llll}
\hline \hline Variables & ADF Test Stat & Critical Value & Trend/Intercept
\end{tabular}


Income per Worker

H.E. Enrollment

Investment

Employment

$\begin{array}{lll}-3.11 & -1.96 & \text { None } \\ -3.76 & -1.96 & \text { None } \\ -2.14 & -1.96 & \text { None } \\ -2.89 & -1.96 & \text { None }\end{array}$

\section{Short and long run Analysis}

For a nonstationary series, ordinary least square results are supurious and are no more justifiable unless we transform the series into differenced form before estimating through OLS. The results derived from OLS in this case are recognised as shortrun analysis. So, here we first present short run analysis of the model discussed in equation 4.

\section{Least Squares Estimation}

Higher education has not posed statistically significant impact in the short run during the study period. The coefficient of physical capital is significant indicating that investment of a contributor to the short run fluctuation of gross domestic product per efficient worker. The exogenous rate of labor growth, technology and depriciation has also imposed statistically no effect on GDP per efficient labor growth. $\mathrm{R}^{2}$ indicates that about one third variation is estimated by this model, which is too low, as the value of F-statistic indicates that model is only significant at $10 \%$ not below it. But the lower value of $\mathrm{R}^{2}$ also confirms that there is no chance of multicollinearity in the estimated system.

Table -3

OLS Estimation Results ${ }^{+}$

Dependent Variable: Log of GDP per Worker ${ }^{+}$

\section{Coefficients}

\section{Constant}

$0.0311^{*}$

$(0.0167)$

Capital/worker

$0.3823 * *$

(0.1565)

$n+g+\psi$

(3.5838)

HE/worker

0.0296

(0.0747)

$\boldsymbol{R}^{2}$

0.297

s.e.e.

0.0684

D.W.

1.73

F-Stat

$2.39 *$

${ }^{+}$Note: all the variables are transformed into differenced log series. Standard errors are in Parentheses

*Significant below $10 \%$ level of significance, **Significant below $5 \%$ level of significance 
These results are not different from earlier empirical work in this area, which confirms that in the shortrun higher education cannot promot growth because of the distributional effects of higher growth. The shift of resources to higher education may not be much fruitful in the short spane of time. This possibility is more relevant in economies which are still in a phase of lower economic development. But if the expansion of higher education is restricted, is there any possibility that it would cause the pace of growth slow? There are two possibilities. First, in the short period asymmetric information will be a hurdle to detect the onset of the slowdown process. In such situation the supply of funds is too small for the economy to return to the fastgrowing steady state. Second, even when the cyclical slump is anticipated correctly, it might be left to take its own path. As the short run growth fluctuations are not empirically connected with the increase in the enrollment of tertiary education, we need to further investigate the question of long run connection between both.

\section{Test for Cointegration}

The ADF test has indicated that all the series are non-stationary at level, exhibiting unit root. The finding that time series may contain a unit root has spurred the development of the theory of non-stationary time series analysis. Engle and Granger (1987) pointed out that a linear combination of two or more non-stationary series may be stationary. If such a stationary linear combination exists, the non-stationary time series are said to be cointegrated. The stationary linear combination is called the cointegrating equation this cointegrating equation is interpreted as a long-run equilibrium relationship among the variables.

We have applied VAR-based cointegration tests using the methodology developed in Johansen (1992, 1995a). The results derived from the Johansens methdology are given in Table 3. One particular point is noteworthy for the conitegration test: maximum Eigen-value and Trace test indicated 1 cointegrating equation, with assumption of no trend and intercept, in both models; keeping growth of labor force, technology and depreciation rate as exogenous variable. But without considering exogenous factor, the trace-test indicates one cointegrating equation in the model with the assumption intercept without trend, whereas maximum Eigen-value test rejected the hypothesis of cointegration. So, the results presented in the second column of Table 4 can be considered on the basis of only trace-test. This contradiction in results can be used for analysis (Johansen and Juselius, 1990).

Table -4

Long run Coefficients

\begin{tabular}{lll}
\hline \hline & \multicolumn{1}{c}{ Dependent Variable: Log of GDP per Worker ${ }^{+}$} \\
\hline \multirow{2}{*}{ Constant } & Without exogenous Factor & With Exogenous Factor \\
& $4.005^{*}$ & \\
Log K/Worker & $(0.901)$ & $0.811^{*}$ \\
& $0.849^{*}$ & $(0.1557)$ \\
Log HE/Worker & $(0.1467)$ & $0.327^{*}$ \\
& $0.291^{*}$ & $(0.0364)$ \\
& $(0.0316)$ & 62.434 \\
\hline \multirow{2}{*}{ Log likelihood } & 59.63 & \\
\hline \hline
\end{tabular}


All the normalized coefficients derived from cointegration test are significant. The relationship between higher education and economic development prevails in the long run. The standard error of the coefficients increased due to exogenous shock; also the intercept term vanished. The shock also contributed to increase in the magnitude of higher education coefficient, reducing the impact of physical capital on economic development. But still the impact of capital is far more than the impact of human capital. We derive that the contribution of higher education in long run growth cannot be overlooked, besides its private benefits. The growth rate of labor force has significantly contributed to mould the impact of human capital for economic uplift.

\section{Conclusion}

The study of relationship between GDP per efficient worker and accumulation of human capital has been investigated empirically in this paper. The results indicate that the correlation relationship between both takes place in the long run, while in shorter time horizon such relationship is still unobservable. The growth model tested here has shown that investment in fixed capital has positive impact on economic uplift. This study also shows that the long run elasticity of income with respect to physical capital stock is different from its share in GDP. Comparing the results of long and short run, it is found that the standard error of coefficients of fixed capital is same in both long and short run, while the standard error of human capital is lower in long term analysis than the short run analysis. There are some fundamental reasons concerning to the ambiguous impact of human capital on economic growth in the short run in case of Pakistan. First, the sharp increase in enrolment, recently, has been damaging to the quality of education supplied. Second the unequal distribution of educational services has held back the efficiency of public expenditures, particularly before the reforms undertaken by higher education commission. Third, the low private return of education has limited the demand for higher education in Pakistan for almost fifty years. Education has been one of the key elements of growth by increasing the pace of workers capabilities, i.e., their leaning by doing capacity enhances through education. It would be interesting to go further in deeper investigation of the issue of higher education for Pakistan. The assessment exercises regarding quality of education, the investigation of inequality of access to education and the investigation of causal relationship among different variables concerning human capital might be further areas to be explored.

\section{REFERENCES}

Azariadis, Costas and Allen Drazen, (1990), "Threshold Externalities in Economic Development," Quarterly Journal of Economics, pp. 501-526.

Barro, Robert J and J. W. Lee, (1996) "International Measures of Schooling Years and Schooling Quality," American Economic Review, Vol. 86(2), pp. 218-23.

Bloom, D., David Canning, and Kevin Chan, (2005) "Higher Education and Economic Development in Africa" Harvard University (September).

Caselli, Francesco and Esquivel, Gerardo and Lefort, Fernando, (1996). "Reopening the Convergence Debate: A New Look at Cross-Country Growth Empirics," Journal of Economic Growth, Vol. 1(3), pp. 363-89. 
Cohen, D., "Tests of the Convergence Hypothesis: Some Further Results", Journal of Economic Growth, Vol. 1, 1996, pp. 351-361.

De Meulmester, J. C., and Rochet, D. (1995), “A causality analysis of the link between higher education and economic development." Economics of Education Review, vol. 14 (4), 351-361.

Denison (1971), "Education and the economics of human capital." R. A. Wykstra (Ed.), Education and Economic Growth. London : Collier-Macmillan ; NY Free Press.

Engle, Robert F. and C. W. J. Granger (1987). "Co-integration and Error Correction: Representation, Estimation, and Testing," Econometrica, 55, 251-276.

Goldin and L. Katz, (1998), “The origins of technology-skill complementary." Quarterly Journal of Economics 113 (3), pp. 693-732.

Granger, C.W.J. (1987), "Investigating causal relations by econometric models and cross spectral methods." Econometrica, 37(3), 424-434.

Hanushek Eric A. and Dongwook Kim, 1995. "Schooling, Labor Force Quality, and Economic Growth," NBER Working Papers 5399.

Islam, N. (1995), “Growth Empirics: A Panel Data Approach,” Quarterly Journal of Economics, 110(4), 1127-70.

Johansen, Soren, (1992), "Testing weak exogeneity and the order of cointegration in UK money demand data, " Journal of Policy Modeling, Vol. 14(3), pp. 313-334.

Johansen, Søren (1995), "Likelihood-based Inference in Cointegrated Vector Autoregressive Models." Oxford: Oxford University Press.

Johansen, Søren and Katarina Juselius (1990), "Maximum Likelihood Estimation and Inferences on Cointegration - with applications to the demand for money," Oxford Bulletin of Economics and Statistics, 52, 169-210.

Krusell, P., and L. Ohanian, J.-V. Ríos-Rull and G. Violante, (2000) "Capital-skill complementarity and inequality: a macroeconomic analysis." Econometrica 6 (5), pp. 1029-1053.

Mankiv, N. G., D. Romer and D. N. Weil (1992), "A Contribution to the Empirics of Economic Growth," Quarterly Journal of Economics, 107, 407-437.

Maski, C. and Wise, F. (1983), “College choice in America.” Cambridge: Harvard University press. 
Osipian, Ararat L., (2007), "Human Capital--Economic Growth Nexus in the Former SovietBloc.” Vanderbilt University Peabody \#514.

Pakistan, Government of, “Economic Survey” Various Issues.

Pencavel, J., (1993) "Higher Education, Economic Growth, and Earnings," American Higher Education and National Growth, Norwell, MA: Kluwer, pp. 51-85.

Pritchett, L. (1996) Measuring outward orientation in LDCs: Can it be done? Journal of Development Economics Vol. 49(2), pp. 307-335.

Psacharopoulos, G. (1994), 'Returns to education: a global update', World Development 22, $1325-1343$.

Psacharopoulos, G. and H. A. Patrinos (2002) "Returns to Investment in Education: A Further Update" World Bank Policy Research Working Paper 2881, September.

Schultz, T. (1988), "Education, investment and returns." Handbook of development economics. The Netherlands: North Holland.

Teichler, U. (1999). "Study Costs, Student Income and Public Policy in Europe". European Journal of Education, 34(1), 7-22.

UNESCO (1999), "Statistical year book 1999." New York, NY: UNESCO, World Bank Report (1998) UNESCO Publishing Berman Press.

Willis, R., and Rosen, S. (1979). Education and self-selection. Journal of Political Economy, 87, S7-S36.

World Bank (1999), "Knowledge for Development." 